II. RECENZJE I OMÓWIENIA

DOI: $10.17951 /$ et.2015.27.254

Joanna Szadura

\title{
MAGICZNE DZIAŁANIE SŁOWEM
}

Joanna Rybarczyk-Dyjewska, Język jako narzędzie magii na przykładzie zaklęć rosyjskich, Kraków: Wydawnictwo Uniwersytetu Jagiellońskiego, 2013, $142 \mathrm{~s}$.

Książka Joanny Rybarczyk-Dyjewskiej to zmodyfikowana rozprawa doktorska autorki. Celem tego opracowania jest „przedstawienie zaklęć ludowych jako wypowiedzi sprawczych, będących sposobem oddziaływania na rzeczywistość, a także próba ustalenia, czym charakteryzuje się język magiczny" (s. 9). Materiałem poddanym analizie są zbiory terenowe zapisane przede wszystkim na terenie północnej Rosji w latach 1953-1993, a wydane pod redakcją Władimira Anikina (Russkie zagovory i zaklinanija. Materialy fol'klornych ekspedicij 1953-1993 gg., Moskva 1998). Niedosyt budzi jednak szczątkowe omówienie zawartości zbioru, który stał się podstawą materiałową omawianego opracowania. Autorka ograniczyła się bowiem jedynie do stwierdzenia, że liczy on dwa i pół tysiąca przekazów. Wykorzystane przekazy dzieli odpowiednio do cykli życia człowieka na trzy grupy: 1) zaklęcia dziecięce, tj. związane z okresem oczekiwania na poród oraz stosowane w pierwszych miesiącach życia dziecka; 2) miłosne - obejmujące przywołanie miłości, zabiegi „odkochania” oraz związane z zawieraniem małżeństwa i 3) dotyczące umierania i pochówku. Wypada żałować, że nie podaje tłumaczeń wykorzystanych tekstów, co ogranicza krąg odbiorców tego opracowania. Mając świadomość różnorodności tekstów magicznych i ich nazewnictwa w języku rosyjskim (zagovor, zaklinanije, nagovor, prigovor, šeptanije, slovo, molitva) oraz trudności ze wskazaniem ich polskiego odpowiednika, autorka deklaruje, że przyjmuje jako neutralne określenie „,tekst magiczny” (które traktuje w kategoriach semiotycznych jako „pewną całość informującą" z punktu widzenia nadawcy), a synonimicznie „formuła magiczna” (z uwagi na ich ludowy i ustny charakter) i systematycznie posługuje się terminem ,zaklęcie” (czego nigdzie nie uzasadnia). Powołuje się przy tym na polską i rosyjską literaturę przedmiotu (Veselovskij, Poznanskij, Vetuchov, Tolstoj, Tolstaja, Judin, Charitonova, Ožegova; Krzyżanowski, Czernik, Niebrzegowska-Bartmińska). Te zagadnienia oraz literaturę przedmiotu (przede wszystkim o charakterze etnolingwistycznym) autorka omawia w części wstępnej.

Pierwszy rozdział zawiera analizy pragmatyczne. Mają one ukazywać strukturę aktów magicznych, ich semantykę oraz mechanizmy działania i funkcje. Badaczka sytuuje przywoływane akty magiczne na tle kulturowym i pragmatycznym. 
Analizowany materiał, wzorem Anny Engelking, dzieli wedle trzech typów działań magicznych: stwarzających, ochraniających i odczyniających. Analizy Engelking dotyczą ludowych rytuałów słownych („, których kontakt człowieka ze sferą sacrum dokonuje się przede wszystkim poprzez mówienie [...] są w istocie aktami nie wyłącznie werbalnymi, lecz całościowymi: werbalno-fizyczno-mentalnymi, i mają moc kreacyjną, moc wywoływania [w przekonaniu uczestników i odbiorców rytuału] realnych skutków w rzeczywistości"), i które, z pragmatycznego punktu widzenia, zostały sklasyfikowane jako: 1) stwarzające pożądany stan rzeczy (zaklinania), 2) ochronne - będące sposobami unikania niepożądanego kontaktu z sacrum, zażegnywania (tj. zapobiegania niepożądanym kontaktom z mocą) oraz 3) odczyniające (zamawiania) ${ }^{1}$. Anna Engelking postuluje, by odrębnej analizie poddać postać językową rytuałów magicznych. Joanna Rybarczyk-Dyjewska korzysta i z tej propozycji badawczej (zob. druga część omawianej pracy).

Blok analiz pragmatycznych otwierają teksty związane $\mathrm{z}$ narodzinami człowieka (czy, jak pisze autorka, z różnymi etapami macierzyństwa). Są to zaklęcia: na poczęcie i lekki poród; na spokój i zdrowie noworodka i chociaż autorka deklarowała, że wśród tych tekstów pojawią się tylko takie, które są związane z pierwszymi miesiącami życia dziecka (zob. s. 9), to dość dużo miejsca zajmują takie, które dotyczą chorób wieku dziecięcego (i nie tylko, bo obszerne fragmenty pracy poświęca się przestrachowi oraz urokom, gryzi, epilepsji, bezsenności, bólowi po uderzeniu, które trapią nie tylko dzieci i które autorka opisuje także jako choroby dręczące dorosłych). W kolejnej części badaczka omawia miłosne teksty magiczne: na urodę, na miłość (tęsknotę), na tłumienie miłości (otsuški) oraz związane ze ślubem i weselem. Całość zamykają teksty dotyczące śmierci i pogrzebu. W każdej grupie zastosowano ten sam układ, tj.: A) działania stwarzające; B) działania ogarniające, a w ich obrębie przede wszystkim: a) wzór cech lub stanu pożądanego, b) prośby do pośredników, c) magia życzenia spełnionego; C) działania odczyniające - tu wydzielano jako kategorie opisu także (oprócz wcześniej wymienionych): zniszczenie, wypędzanie, odsyłanie, obietnicę, ofiarę, wymianę. Autorka, chcąc wyjaśnić symboliczny sens poszczególnych działań i formuł słownych, korzysta ze zróżnicowanej literatury przedmiotu, dość dowolnie mieszając tradycje słowiańskie (głównie polskie i rosyjskie). Niekiedy doprowadza to do powierzchownych uproszczeń i nie ukazuje specyfiki rytuałów zaczerpniętych z rosyjskiej tradycji ludowej.

Magia miłosna obejmuje zaklęcia na urodę (mające zwrócić uwagę osoby ukochanej), na miłość, od tęsknoty i przeciw miłości. W tej grupie znalazły się także zaklęcia dotyczące zawarcia małżeństwa. Autorka ma świadomość odmienności tych rytuałów (przywołuje w tym miejscu np. stanowisko Kowalskiego i Kotuli), a mimo to umieszcza je wśród tekstów o funkcji miłosnej. Nie powinny one znaleźć się w tej grupie. Podobnie jak formuły związane ze śmiercią i pogrzebem, należało je omówić oddzielnie.

Druga część publikacji (s. 95-121) to analizy językowe. Na tę część opracowania złożyło się omówienie: a) środków służących wyrażaniu woli mówiącego: pobudzanie do działania (np. użycie trybu rozkazującego wyrażające prośby, nakazy, rady

${ }^{1}$ Chodzi o tekst Rytuały słowne w kulturze ludowej. Próba klasyfikacji, „Język a Kultura", t. 4, 1991, s. 75-87. 
i zalecenia; stosowanie zwrotów ekspresywnych); życzenia (i ich językowe wykładniki), konstrukcje porównawcze (wskazujące na sposób, jakość i ilość) oraz wyrażenia performatywne. Następnie omówiono grupę słów magicznych uzupełniających i wzmacniających (powtórzeń, tautologii, wyliczeń i rymowanek).

Podsumowując swoje obserwacje, autorka stwierdza, że formuły magiczne mają cechy tekstów ustnych, a najważniejsze jest dla nich osadzenie w specyficznej sytuacji oraz intencja działania słowem (stwarzającego, ochraniającego czy odczyniającego), wynikająca z wiary w jego skuteczność. 